\title{
Protective effects of orally applied fullerenol nanoparticles in rats after a single dose of doxorubicin
}

\author{
Ivana Dj. Ičević ${ }^{1}$, Saša N. Vukmirović ${ }^{2}$, Branislava U. Srđenović ${ }^{3}$ Jan J. Sudji ${ }^{4}$, Aleksandar N. Djordjevic ${ }^{1}$, \\ Rade M. Injac ${ }^{5}$, Velibor M. Vasović ${ }^{2}$ \\ ${ }^{1}$ Department of Chemistry, Faculty of Science, University of Novi Sad, Novi Sad, Serbia \\ ${ }^{2}$ Department of Pharmacology and Toxicology, Medical Faculty, University of Novi Sad, Novi Sad, Serbia \\ ${ }^{3}$ Department of Pharmacy, Medical Faculty, University of Novi Sad, Novi Sad, Serbia \\ ${ }^{4}$ The Institute for the Health Protection of Workers Novi Sad, Novi Sad, Serbia \\ ${ }^{5}$ Institute of Pharmaceutical Biology, Faculty of Pharmacy, University of Ljubljana, Ljubljana, Slovenia
}

\begin{abstract}
Polyhydroxylated, water soluble, fullerenol $\mathrm{C}_{60}(\mathrm{OH})_{24}$ nano particles (FNP) in vitro and in vivo models, showed an expressive biological activity. The goal of this work was to investigate the potential protective effects of orally applied FNP on rats after a single dose of doxorubicin (DOX) $(8 \mathrm{mg} / \mathrm{kg}$ (i.p.)) $6 \mathrm{~h}$ after the last application of FNP. After the last drug administration, the rats were sacrificed, and the blood and tissues were taken for the analysis. Biochemical and pathological results obtained in this study indicate that fullerenol (FNP), in $\mathrm{H}_{2} \mathrm{O}$ :dimethyl sulfoxide (DMSO) $(80: 20, \mathrm{w} / \mathrm{w})$ solution given orally in final doses of $10,14.4$, and $21.2 \mathrm{mg} / \mathrm{kg}$, three days successively, has the protective (hepatoprotective and nephroprotective) effect against doxorubicin-induced cytotoxicity via its antioxidant properties.
\end{abstract}

Keywords: Fullerenol $\bullet$ Nano particles $\bullet$ Doxorubicine $\bullet$ In vivo $\bullet$ Oral application

SCIENTIFIC PAPER

UDC 546.26:615.33:57.08

Hem. Ind. 65 (3) 329-337 (2011)

doi: 10.2298/HEMIND101231006|

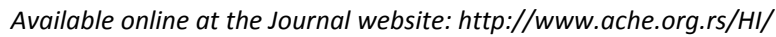

Doxorubicin (DOX) is an anthracycline antibiotic, one of the most effective and commonly used antineoplastic agents, with a very wide spectrum of antitumor efficacy [1]. One major mechanism underlying the antineoplastic action of DOX concerns its ability to intercalate into the DNA helix and/or bind covalently to proteins involved in DNA replication and transcription (topoisomerase II) [2]. DOX can also interact with mitochondria and bind to cardiolipin blocking the binding of mitochondrial creatine kinase to mitochondrial membranes [3]. Additionally, the increase in DOX redox cycling by complex I of the mitochondrial respiratory chain leads to an increase in reactive oxygen species (ROS) production. These DOX derivates react with oxygen and form superoxide radicals and/or DOX reacts with iron generating $\mathrm{H}_{2} \mathrm{O}_{2}$ [4]. The mechanism of DOX-induced cardiotoxicity also includes expression of nitric oxid syntheses, changes in calcium homeostasis and alteration of molecular signalling $[5,6]$. All these interactions lead ultimately to cell death.

The clinical usefulness of DOX is restricted, due to several acute and chronic side effects, especially a dose-dependent myocardial injury, which can cause congestive heart failure. This anticancer drug also affects other

Correspondence: I.Dj. Ičević, Department of Chemistry, Faculty of Science, University of Novi Sad, Trg Dositeja Obradovica 3, 21000 Novi Sad, Serbia.

E-mail: ivana.icevic@dh.uns.ac.rs

Paper received: 31 December, 2010

Paper accepted: 24 January, 2010 organs like the brain, kidneys, liver and skeletal muscles $[7,8]$.

Several attempts have been made to attenuate DOX side effects, including dosage optimization, combined therapy with antioxidants and/or compounds with antiapoptotic activity, development of efficient delivery systems, as well as synthesis and use of analogues [9].

Fullerens are closed spherical molecules, shaped like a soccer ball and made entirely of carbon atoms. Functionalized fullerenes are one of the many different classes of compounds that are currently being investigated in the rapidly emerging field of nanoscience, especially nanomedicine [10-12]. Chemical modification of fullerenes, $\mathrm{C}_{60}$, into water soluble polyhydroxylated nanoclusters, make them interesting for biological research. The results of latter research in this area suggest that the predominant forms of fullerenol in aqueous environment are clusters with a mean size of $100 \mathrm{~nm}$. The size evolution of fullerenol clusters is dynamic and is sensitive to changes in environmental conditions like $\mathrm{pH}$ and temperature [13].

Fullerenols, $\mathrm{C}_{60}(\mathrm{OH})_{n}$, polyhydroxylated derivatives of fullerene $C_{60}$, are being extensively investigated because of their great potential as antioxidants. Especially, FNP, administered intraperitoneally or intravenous, in vitro and in vivo models, showed an expressive biological activity. FNP might act as antioxidative [14], cell protective [15], radioprotective [16], and geno-protective agent [17], cardio and hepato-protector in doxorubicin-induced stress in vivo mo dels [18]. In current 
literature there are no available data on the effects of orally applied fullerenol.

Yin et al. have found that molecular as much as supramolecular properties of watersoluble derivatives of fullerenol, involving aggregation into nanoparticles/nanostructures, have a significant impact on their biological activities. In addition, size may influence the distribution of nanoparticles in cells and in tissues [19].

The results of Jing-Ying et al. [20] showed that pretreatment with fullerenol $\left(\mathrm{C}_{60}(\mathrm{OH})_{x}, x: 3-24\right)$ could protect tissues against $\mathrm{CCl}_{4}$-induced oxidative stress in rats by improving the antioxidant ability. Our recent experiments indicate that oral application of FNP $(10.0,14.4$ and $21.2 \mathrm{mg} / \mathrm{kg}$ ) $60 \mathrm{~min}$ before i.p. administration of $\mathrm{CCl}_{4}(0.5 \mathrm{ml} / \mathrm{kg})$ did not have significant influence on serum activity of alanine aminotransferase and aspartate aminotransferase, as well as the concentration of blood urea and creatinine. The histological studies of the heart and liver indicated that they were not damaged by $\mathrm{CCl}_{4}$ (unpublished data).

The scope of this experiment was to investigate the potential protective effects of orally applied FNP (dissolved in $\mathrm{NaCl}$ (0.9\%):DMSO (80:20 w/w) solution) in rats after a single dose of intraperitoneal application of DOX.

\section{MATERIALS AND METHODS}

\section{Chemicals and reagents}

Fullerenol $\left(\mathrm{C}_{60}(\mathrm{OH})_{24}\right)$ was synthesized and characterized from polybromine derivative $\mathrm{C}_{60} \mathrm{Br}_{24}$ that was synthesized in a reaction of $\mathrm{C}_{60}$ in $\mathrm{Br}_{2}$ with $\mathrm{FeBr}_{3}$ as the catalyst [21]. Fifty (50) mg of $\mathrm{C}_{60} \mathrm{Br}_{24}$ was mixed in $5 \mathrm{~cm}^{3}$ of $\mathrm{NaOH}(\mathrm{pH} \mathrm{10})$ for $2 \mathrm{~h}$ at room temperature. After the reaction was completed the solvent was evaporated at $40{ }^{\circ} \mathrm{C}$, and the mixture was rinsed five times with 10 $\mathrm{cm}^{3}$ portions of $80 \%$ ethanol. Water solution $(20 \mathrm{ml})$ of fullerenol with residual amounts of $\mathrm{NaOH}$ and $\mathrm{NaBr}$ was applied to the top of the combined ion exchange resin (20 g DOWEX MB50 QC121815 R1) and eluted with demineralized water until discoloration. The water solution of fullerenol $(\mathrm{pH} 7)$ was evaporated under low pressure; and a dark brown powder substance left. Fullerenol as dissolved in a sterilized and apyrogenic $\mathrm{NaCl}$ (0.9\%):DMSO $(80: 20 \mathrm{w} / \mathrm{w})$ solution (in concentration $10.0,14.4$ and $21.2 \mathrm{mg} / \mathrm{mL}$ ) inside a laminar flow cabin immediately before use.

\section{Physical determination of Fullerenol $\left(\mathrm{C}_{60}(\mathrm{OH})_{24}\right)$}

FTIR: $\mathrm{C}_{60}(\mathrm{OH})_{24}$ has following characteristic peaks at 3427, 1627, 1419, $1080 \mathrm{~cm}^{-1} \cdot{ }^{13} \mathrm{C}-\mathrm{NMR}\left(\mathrm{D}_{2} \mathrm{O}\right)$ : singlet peaks at $\delta 169.47 \mathrm{ppm}$ and multiplet peak at $\delta 160-110$ ppm. MALDI MS $(\mathrm{m} / \mathrm{z}): 720\left(\mathrm{C}_{60+}\right), 993\left(\mathrm{C}_{60}(\mathrm{OH})^{16+}\right)$, $1043\left(\mathrm{C}_{60}(\mathrm{OH})^{19+}\right), 1061\left(\mathrm{C}_{60}(\mathrm{OH})^{20+}\right), 1128\left(\mathrm{C}_{60}(\mathrm{OH})^{24+}\right)$. DTG, DTA and TG show two thermal changes, in a temperature range of $120-395{ }^{\circ} \mathrm{C}$, which corresponds to the loss of mass of $35.7 \%$ (23.7 $\mathrm{OH}$ groups) and at a temperature of $430{ }^{\circ} \mathrm{C}$ the evident loss of mass was $64.3 \%$ (this is the sublimation temperature of $C_{60}$ ). Elementary analysis of FNP provided the following: C $63.0 \%, \mathrm{H}-2.0 \%$, which coincides with theoretically calculated values: $\mathrm{C}-63.83 \%, \mathrm{H}-2.13 \%$.

Particle size distribution and zeta potential of FNP in $\mathrm{H}_{2} \mathrm{O}$ :DMSO (80:20 w/w) solution are presented in Table 1 (Zetasizer Nano, Malvern Instruments). Ten percent, $d(0.1)$, of particles have dimensions in the range of 33$-63 \mathrm{~nm}$; fifty percent, $d(0.5)$, of particles have dimensions in the range of $60-87 \mathrm{~nm}$ and ninety percent, $d(0.9)$, of particles have dimensions in the range of 105-132 nm.

Table 1. Particle number distribution, $d(\mathrm{~nm})$, and zeta potential, $\zeta(\mathrm{mV})$, of FNP in $\mathrm{H}_{2} \mathrm{O}$ :DMSO $(80: 20 ; w / w)$ solution

\begin{tabular}{lcccc}
\hline FNP Concentration, $\mathrm{mg} / \mathrm{ml}$ & $d(0.1)$ & $d(0.5)$ & $d(0.9)$ & $\zeta$ \\
\hline $10.0 \mathrm{mg} / \mathrm{ml}$ & 33 & 60 & 105 & -20.0 \\
$14.4 \mathrm{mg} / \mathrm{ml}$ & 63 & 87 & 132 & -14.9 \\
$21.2 \mathrm{mg} / \mathrm{ml}$ & 63 & 87 & 132 & -12.8 \\
\hline
\end{tabular}

These parameters corresponds to DLS measuring of fullerenol nanoparticles in $\mathrm{H}_{2} \mathrm{O}$ :DMSO $(80: 20 \mathrm{w} / \mathrm{w})$ solution. Change of FNP dimensions and particle size distribution in $\mathrm{H}_{2} \mathrm{O}$ :DMSO $(80: 20 \mathrm{w} / \mathrm{w})$ solution did not occur after addition of serum 120 min later at $25^{\circ} \mathrm{C}$ or after temperature variation at $37^{\circ} \mathrm{C}$. A multimode quadrex SPM with Nanoscope Ille controller (Veeco Instruments, Inc.), operated under ambient conditions, was used in this work. Surface topography and phase images were simultaneously acquired by standard AFM tapping mode using a commercial NanoScience-Team Nanotec GmbH SNC (Solid Nitride Cone) AFM probe, with the tip radius lower than $10 \mathrm{~nm}$. The used surface is highly orientated pyrolytic graphite (HOPG). Figure 1 shows tapping images of large particle of fullerenol in $\mathrm{H}_{2} \mathrm{O}$ :DMSO (80:20 w/w) solution.

The large particle about $95 \mathrm{~nm}$ consist of a few (5-7) smaller particles with the size of about $25 \mathrm{~nm}$. Particles had nearly spherical shape as can be seen in Figure 1d. The peak-to-valley measurements showed that maximum peak height was at about $4.5 \mathrm{~nm}$ and smaller peaks were at the 2.0, 2.5. $3.52 \mathrm{~nm}$ (Figure 1c).

DOX (Adriablastina ${ }^{\circledR}$ ) for i.v. administration was obtained from Pharmacia \& Upjohn (Milan, Italy).

The solution for the i.p. application was dissolved in a sterilized and apyrogenic $0.9 \% \mathrm{NaCl}$ solution $(2 \mathrm{mg} / \mathrm{ml}$ ) inside a laminar flow cabin immediately before use.

\section{Animals models}

Male Wistar rats (Military Medical Academy, Belgrade, Serbia) were obtained at 7 weeks of age, quarantined and housed 3 per cage at a $22-23{ }^{\circ} \mathrm{C}$ room temperature, $55 \pm 10 \%$ humidity and a $12 \mathrm{~h}$ light/dark 


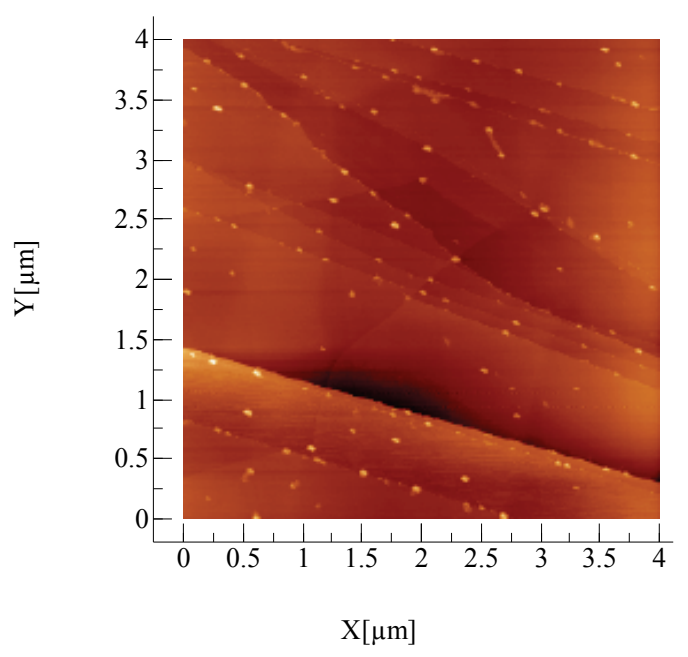

(a)

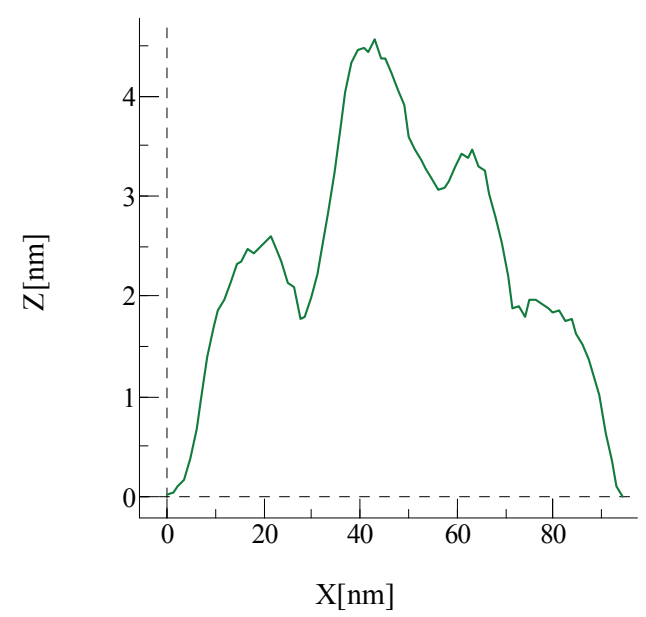

(c)
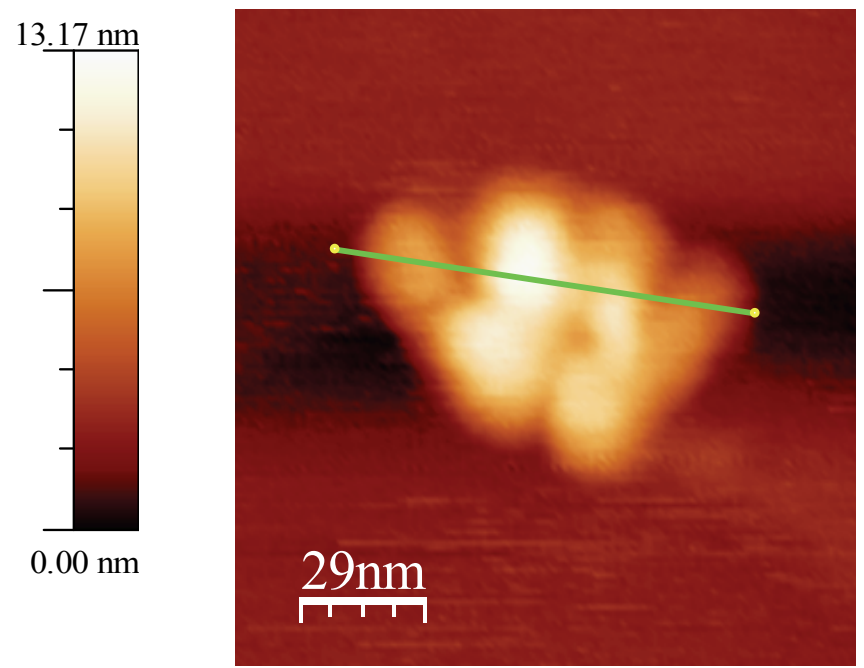

(b)

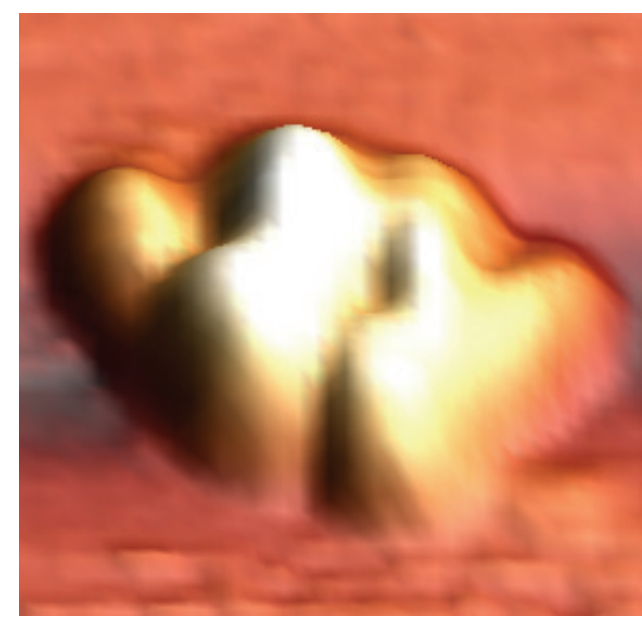

(d)

Figure 1. AFM images of fullerenol large particle in $\mathrm{H}_{2} \mathrm{O}: D M S O(80: 20 ; w / w)$ solution: a) homogeneous distribution of FNP; b) AFM image $140 \times 140 \mathrm{~nm}^{2}$ of the large particle, about $95 \mathrm{~nm}$ on the HOPG surface; c) corresponding cross-section of large particle; $d$ ) $3 D$ image of the larger particle on the HOPG surface.

cycle. They had free access to a standard laboratory diet and water. All experiments were conducted in accordance with the European Convention for the protection of vertebrate animals used for experimental and other scientific purposes (ETS 123).

\section{Statistical analysis}

The data were analyzed using analysis of variance (ANOVA) factorial experiment. Comparison of mean values of measured parameters was performed by Duncan's multiple range test, for the level of significance $p<0.05$. The results are shown graphically. For each analyzed parameter is given the least significant difference, LSD. Values for each treatment that are marked in the tables with the same letter are not significantly different for $p<0.05$ level of significance. The highest value is indicated by the letter "a", then the values decrease in alphabetical order. The graph shows the standard deviation for each treatment.

\section{Experimental design}

Untreated control group were treated (o.a.) three days successively with saline only. Tree groups of animals were treated (o.a.) three days successively with FNP in $\mathrm{H}_{2} \mathrm{O}$ :DMSO $(80: 20 \mathrm{w} / \mathrm{w})$ solution in dose of: 10 , 14.4 and $21.2 \mathrm{mg} / \mathrm{kg}$, respectively. One group of animals were treated (i.p.) with DOX in a single dose of 8 $\mathrm{mg} / \mathrm{kg}$. Protected group of rats were treated (o.a.) three days successively with FNP in $\mathrm{H}_{2} \mathrm{O}$ :DMSO $(80: 20 \mathrm{w} / \mathrm{w})$ solution in dose of $10 \mathrm{mg} / \mathrm{kg}$, and after $6 \mathrm{~h}$ of last dose were treated with (i.p.) DOX $8 \mathrm{mg} / \mathrm{kg}$. All animals were sacrificed after $48 \mathrm{~h}$ by urethane anesthesia.

The animals were randomly divided into six groups for six animals per group (Table 2).

I - oral application of $0.9 \% \mathrm{NaCl}$ solution three days successively (control group); 
Table 2. Animal groups and experimental design

\begin{tabular}{|c|c|c|c|c|c|c|}
\hline Group & Description & $\begin{array}{c}\text { Number of animals at } \\
\text { the beginning }\end{array}$ & $\begin{array}{c}\text { Number of surviving } \\
\text { animals }\end{array}$ & Administration-agenda & $\mathrm{DOX}, \mathrm{mg} / \mathrm{kg}$ & $\mathrm{FNP}, \mathrm{mg} / \mathrm{kg}$ \\
\hline I & Healthy control & 6 & 6 & o.a. 3 days saline & - & - \\
\hline II & FNP-10.0 & 6 & 6 & o.a. 3 days & - & 10.0 \\
\hline III & FNP-14.4 & 6 & 6 & o.a. 3 days & - & 14.4 \\
\hline IV & FNP-21.2 & 6 & 6 & o.a. 3 days & - & 21.2 \\
\hline V & FNP/DOX & 6 & 6 & o.a. 3 days/i.p. after $6 \mathrm{~h}$ & 8 & 10.0 \\
\hline VI & DOX & 6 & 6 & i.p. & 8 & - \\
\hline
\end{tabular}

II - oral application of FNP in $\mathrm{H}_{2} \mathrm{O}$ :DMSO (80:20, $\mathrm{w} / \mathrm{w}$ ) solution in final dose of $10 \mathrm{mg} / \mathrm{kg}$, three days successively (operating control group);

III - oral application of FNP in $\mathrm{H}_{2} \mathrm{O}$ :DMSO (80:20, $\mathrm{w} / \mathrm{w}$ ) solution in final dose of $14.4 \mathrm{mg} / \mathrm{kg}$, three days successively;

IV - oral application of FNP in $\mathrm{H}_{2} \mathrm{O}$ :DMSO (80:20, $\mathrm{w} / \mathrm{w}$ ) solution in final dose of $21.2 \mathrm{mg} / \mathrm{kg}$, three days successively;

V - FNP/DOX group - rats received FNP (o.a.) 10 $\mathrm{mg} / \mathrm{kg}, 30 \mathrm{~min}$ before DOX $8 \mathrm{mg} / \mathrm{kg}$ (i.p.), three days successively; $6 \mathrm{~h}$ after the last FNP application, rats receive DOX $8 \mathrm{mg} / \mathrm{kg}$ (i.p.), at once (protected group),

$\mathrm{VI}$ - DOX group - rats received DOX $8 \mathrm{mg} / \mathrm{kg}$ (i.p.), at once.

\section{Body weight and coefficient of liver weight}

The coefficient of heart and liver to body weight was calculated as the ratio of organ tissues (wet weight, $\mathrm{mg}$ ) to body weight (g). During autopsy, the hearts and livers were excised and weighed. Samples of every heart and liver were fixed in $10 \%$ buffered formalin for histological analysis. All tissue samples were embedded in paraffin. Sections ( $3 \mu \mathrm{m}$ in thickness) of the embedded tissue were stained with hematoxylin-eosin and periodic acid schiff (PAS) for light microscopy observations, as it was done in previous research [22].

During treatment period, the body weight of each rat was checked. After sacrifice, the body weight was measured and various tissues/organs were collected. Table 3 shows body weight and the coefficients of liver

Table 3. Body weight of rats and coefficients of liver after sacrificing ( $p<0.05$; values followed by the same letter are not statistically different for $p<0.05$ )

\begin{tabular}{lcc}
\hline Treatment & Body weight, $\mathrm{g}$ & K liver, g \\
\hline I & $182.5 \pm 11.24 \mathrm{~b}$ & $43.38 \pm 1.26 \mathrm{ab}$ \\
II & $202.5 \pm 12.18 \mathrm{ab}$ & $43.93 \pm 3.01 \mathrm{ab}$ \\
III & $209.2 \pm 10.98 \mathrm{a}$ & $45.96 \pm 3.49 \mathrm{a}$ \\
IV & $185.2 \pm 26.70 \mathrm{~b}$ & $38.47 \pm 0.46 \mathrm{c}$ \\
$\mathrm{V}$ & $158.5 \pm 8.34 \mathrm{c}$ & $43.64 \pm 1.69 \mathrm{ab}$ \\
$\mathrm{VI}$ & $144.5 \pm 13.75 \mathrm{c}$ & $41.72 \pm 1.78 \mathrm{~b}$ \\
\hline LSD & 21.58 & 2.918 \\
\hline
\end{tabular}

expressed as mg (wet weight of tissues)/g (dead body weight).

\section{Biochemical analysis}

Blood for analysis was taken via heart puncture after opening the thoracic region. Serum was used for analysis of enzymatic activity (ALT and AST) and for analysis of urea blood level. All analyses were done in accordance with previously used protocols [23,24]. Each kidney and liver was removed from the sacrificed animals and placed into an ice-cold solution. The adipose tissues were trimmed off. Each organ was minced and homogenized in a Tris-buffer solution $(\mathrm{pH} 7.4$; organ:buffer, 1:10, w/w). MDA determination in liver and kidney tissues were analyzed according to the protocol [23].

\section{AFM Analysis}

Multimode quadrex SPM with Nanoscope Ille controller (Veeco Instruments, Inc.), operated under ambient conditions was used in this work. Surface topography and phase images were simultaneously acquired by standard AFM tapping mode using a commercial NanoScience-Team Nanotec GmbH SNC (Solid Nitride Cone) AFM probe, with the tip radius lower than 10 $\mathrm{nm}$. Used surface is HOPG.

\section{RESULTS}

The final body weights of the FNP/DOX and DOX treated animals (V and VI group) were less when compared to the untreated control group of rats. For all groups measured in comparison to the untreated control group (I), the coefficient is not significantly different except for the FNP (oral application in dose of 21.2 $\mathrm{mg} / \mathrm{kg}$ ) and for the treated group (IV) (Figure 2).

Rats received i.p. DOX (VI) in a single dose had significantly higher levels of serum ALT compared with all other groups. Animals from the group protected by a three-day oral application of FNP (V) and from operating control group (orally administrated FNP, group II) had ALT levels comparable to the control group that received saline only (I) (Figure 3 ). 


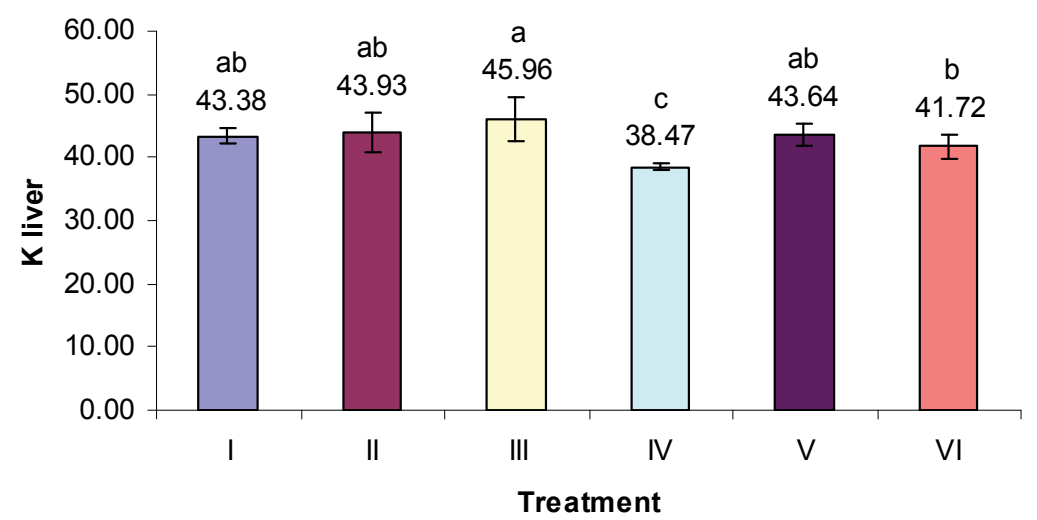

Figure 2. Coefficient of liver weight.

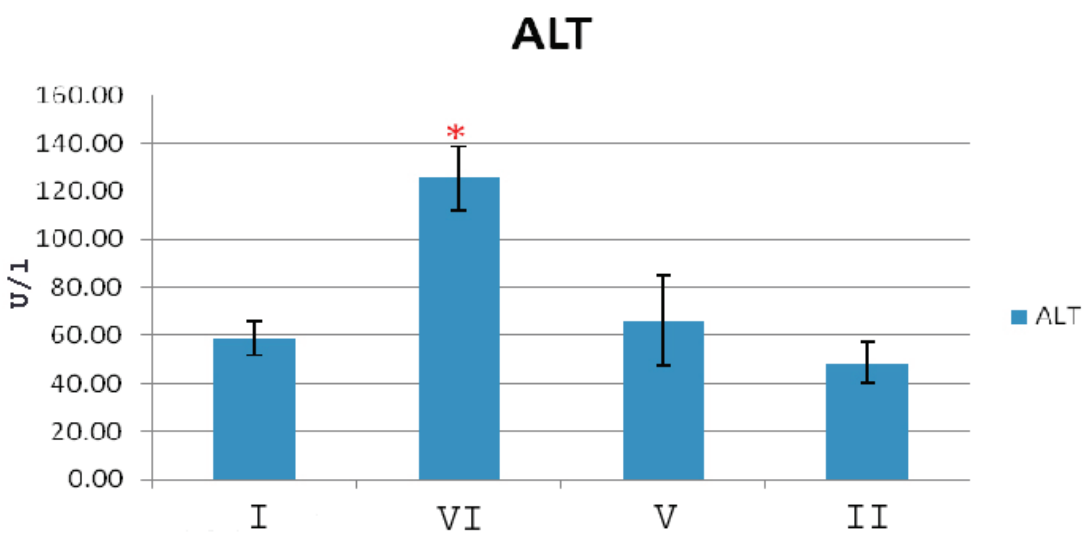

Figure 3. Alanine aminotransferase in rat serum. X-axis shows different groups; $Y$-axis shows ALT level in U/L. ${ }^{*}-$ significant difference from the corresponding group for the value $p<0.05$ ).

Levels of AST in serum did not change significantly in all examined groups of animals (Figure 4).

The significant increase of urea serum levels was measured in the group that received i.p. DOX in a single dose $(\mathrm{VI})$, while the values of urea concentration in protected group FNP/DOX (V) and operating control group FNP (II) was comparable to the control group of animals treated only with saline (I) (Figure 5).
It was evident that there was a significant increase of MDA level in the liver of rats received i.p. DOX in a single dose(VI). MDA levels in protected group FNP/ /DOX (V) and operating control group FNP (II) was comparable to the control group animals who received saline only (I) (Figure 6).

The significant increase in kidney MDA level was obtained in the group that received i.p. DOX in a single

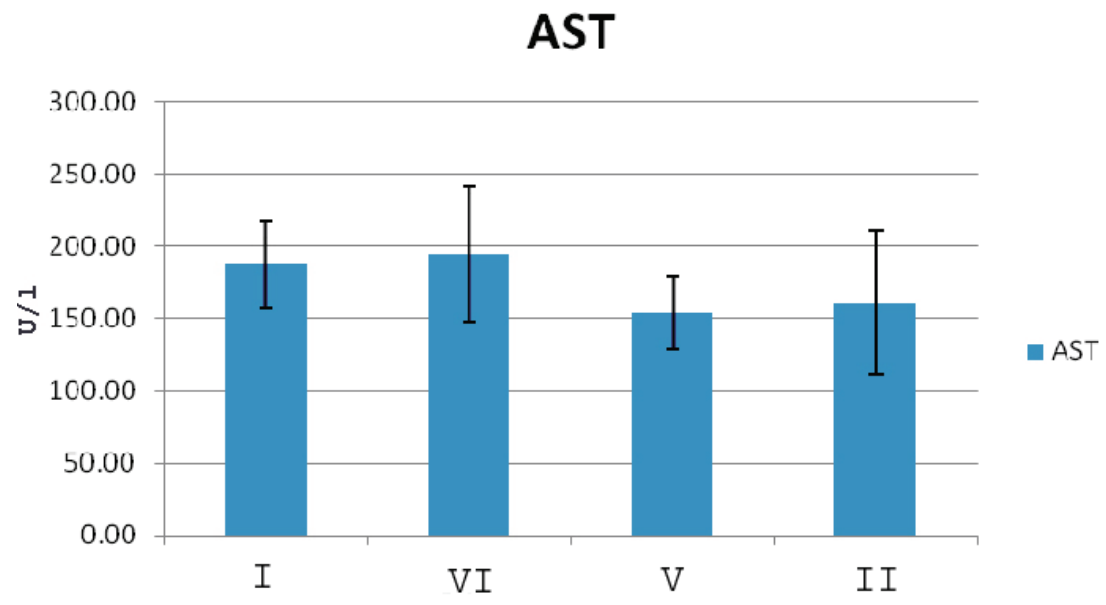

Figure 4. Aspartate aminotransferase in rat serum. $x$-Axis shows different groups; $y$-axis shows AST level in U/L. $\left(^{*}-\right.$ significant difference from the corresponding group for the value $p<0.05$ ). 


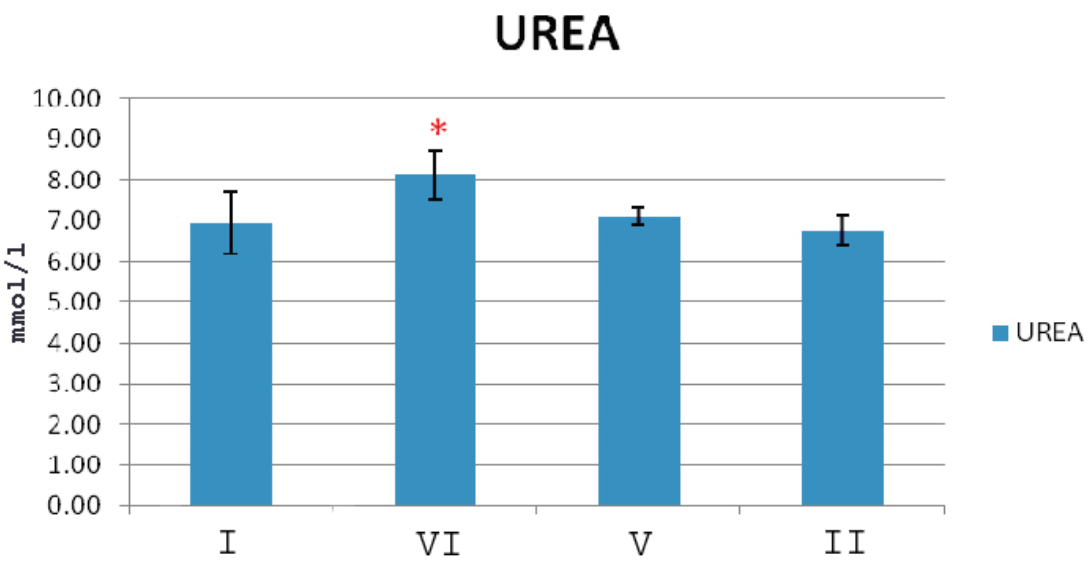

Figure 5. Urea in rat serum. $x$-Axis shows different groups; $y$-axis shows urea level in $\mathrm{mmol} / \mathrm{L}\left({ }^{*}\right.$-significant difference from the corresponding group for the value $p<0.05$ ).

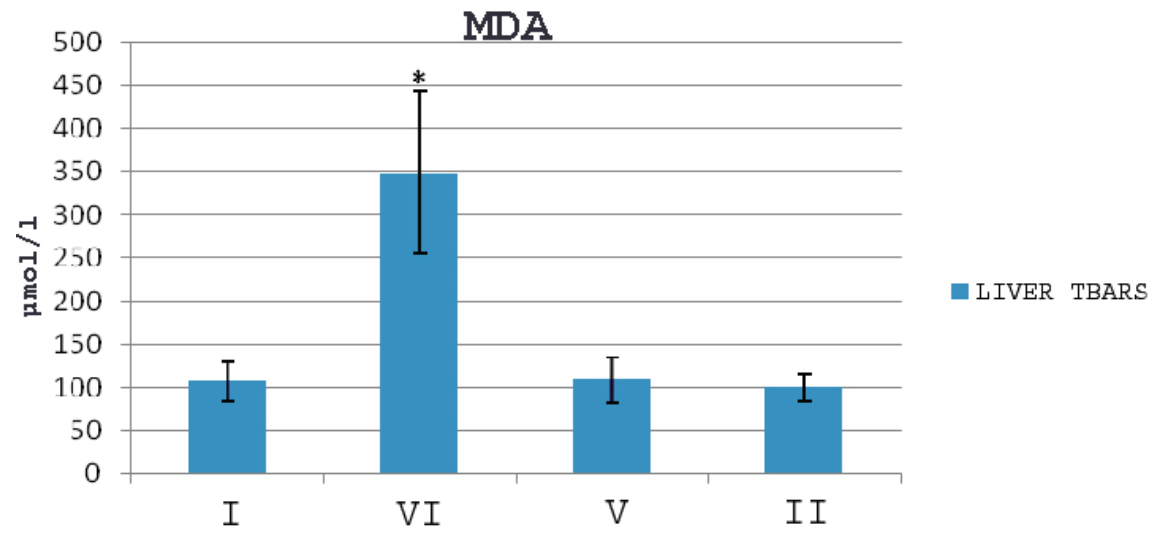

Figure 6. MDA level in rat liver. $x$-Axis shows different groups; $y$-axis shows MDA liver level in $\mu m o l / L{ }^{*}$ - significant difference from the corresponding group for the value $p<0.05 ;$ TBARS - tiobarbituric acid reactive substances, an index of malonic acid (MDA) production.

dose (VI), and also in protected group FNP/DOX (V), although the MDA level in the protected group was less than in DOX-treated group (Figure 7). MDA level in operating control group FNP (II) was comparable to the control group of animals who received saline orally (I).

\section{DISCUSSION}

The analyses of ALT serum level in animals that were treated with i.p. DOX in a single dose showed a significant increase compared with values obtained for all other treated groups of animals (Figure 3). Group

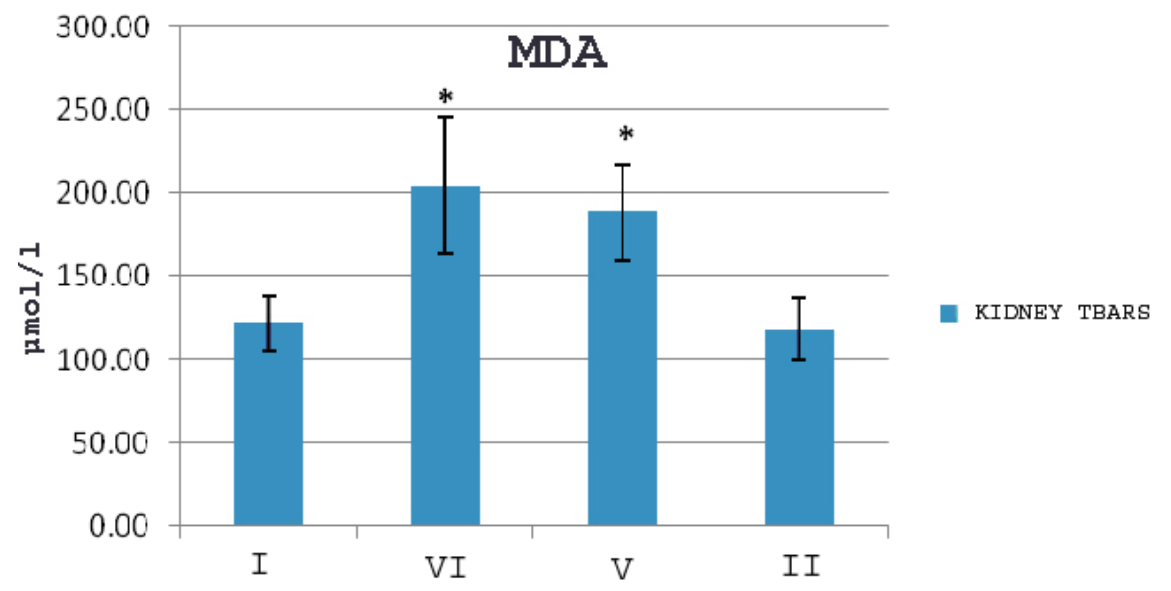

Figure 7. MDA level in rat kidneys. $x$-Axis shows different groups; $y$-axis shows MDA kidney level in $\mu$ mol/L ${ }^{*}$-significant difference from the corresponding group for the value $p<0.05$ ). 
protected from acute toxicity of DOX with three days successively oral application of FNP, and the other groups of animals that also received orally FNP for three days, had ALT levels comparable with the control group. These results indicate a hepatoprotective action of orally inoculated FNP which is in compliance with the published data of i.p. application of FNP [18,22,24,25].

The AST serum levels in animals that received i.p. DOX, only, was correlated with the control group AST level (Figure 4). AST values in group protected from acute DOX toxicity with o.a. of FNP as well as the group of animals that received only FNP orally for three days had lower AST levels compared with control group. Very high levels of AST in serum of control animals group may be the consenquence of stress during the manipulation of animals or the error in experimental analysis. Obtained values indicate that the three day oral pretreatment with FNP had a hepatoprotective effect from acute toxicity caused by single i.p. dose of DOX.

The significantly higher values of urea in rats serum were measured in the group of animals treated with i.p. DOX in a single dose compared with control group (Figure 5). The animals protected from DOX acute toxicity with oral application of FNP for three days and the group of animals received FNP dose orally, also for three days, had the same urea levels as the control group. Obtained values indicate nontoxic and nephroprotective effects of orally administrated FNP (in the final dose of $10 \mathrm{mg} / \mathrm{kg}$ ) from acute i.p. DOX application (in the final dose of $8 \mathrm{mg} / \mathrm{kg}$ ). The results are in accordance with previously published data regarding nephroprotective action of i.p. applied FNP [23].

Liver damage caused by i.p. application of DOX in a single dose of $8 \mathrm{mg} / \mathrm{kg}$ was manifested two days after treatement as a significant increase of liver MDA levels compared with control animals group (Figure 6). MDA values in liver tissue of animals pretreated for three days with oral application of FNP were significantly reduced compared with previosly mentioned DOX group (VI) and were in correlation with control (I). Oral administration of FNP for three days in dose of $10 \mathrm{mg} / \mathrm{kg}$ did not cause any toxic effect on liver and had a protective role against DOX applied i.p.in a single dose of $8 \mathrm{mg} / \mathrm{kg}$. These MDA level measurements suggest hepatoprotective action of orally applied FNP from acute DOX toxicity and are compatible with data about hepatoprotective effect of i.p. and i.v. administrated FNP.

Single dose application of DOX increases twice the level of kidney MDA compared with control (Figure 7). Oral pretreatment with FNP decreased MDA level in comparison with a group of animals treated only with DOX. The MDA values in rats that received oral dose of FNP for three days were in correlation with MDA levels of control group. Orally applied FNP (for three days in dose of $10 \mathrm{mg} / \mathrm{kg}$ ) did not cause any toxic effect on kid- ney and showed a protective role against i.p. cytotoxicity induced by DOX applied i.p. (in a single dose of 8 $\mathrm{mg} / \mathrm{kg}$ ). Obtained results indicate nephroprotective effect of o.a. FNP and are also consistent with the protective action of i.p. administrated FNP against nephropathy $[23,26]$. These data show better hepatoprotection than nephroprotection from acute DOX toxicity as a result of antioxidative action of oral pretreatement with FNP for three days.

Oral application of FNP for three days in final doses of $10,14.4$ and $21.2 \mathrm{mg} / \mathrm{kg}$ did not cause any visible pathological changes in tissues of kidney, liver and small intestine. There was no evidence of pathological changes in the intestinal mucosa. Single-layer cylindrical epithelium was completely preserved without any inflammatory changes in the lamina propria (mucous membrane) in all examined tissue samples. Pathological changes of renal parenchyma were not observed in any analyzed group. Examined cortical structures had preserved glomerulus as well as proximal and distal tubules. Medullary collecting ducts also had normal lumen with no content. Pathohistological analyses of samples from the sixth (VI) group showed hepatocytes characterized by fine-grained cytoplasm, as an indication of developed parenchymatous degeneration, initial but also reversible pathological process. Liver preparations of groups II-V indicated the absolute preservation of parenchyma, hepatocytes had normal morphology, without present forms of parenchymatous degeneration, which is consistent with the control group. Oral application of FNP in $\mathrm{H}_{2} \mathrm{O}$ :DMSO $(80: 20, \mathrm{w} / \mathrm{w})$ solution in final doses of $10,14.4$, and $21.2 \mathrm{mg} / \mathrm{kg}$, three days successively, in all analyzed tissues (liver, kidney and small bowel segment) shows protective effect against citotoxicity caused by DOX administrated i.p. in a single dose of $8 \mathrm{mg} / \mathrm{kg}$.

\section{CONCLUSION}

All previously published investigations with FNP as an organo-protector against cell damage induced by a single dose of DOX were established to evaluate protective potential of parenteral administration of FNP. These results are the first evidence of cytoprotective activity of orally applied FNP, in $\mathrm{H}_{2} \mathrm{O}$ :DMSO (80:20 w/w) solution, as a pretreatment, in final doses of 10, 14.4, and $21.2 \mathrm{mg} / \mathrm{kg}$, three days successively toward acute injury caused by single dose of DOX. Results obtained in this study indicate that fullerenol (FNP) in $\mathrm{H}_{2} \mathrm{O}$ :DMSO $(80: 20, w / w)$ solution in final doses of $10,14.4$, and $21.2 \mathrm{mg} / \mathrm{kg}$, three days successively, given orally, may play a hepatoprotective and nephroprotective role in doxorubicin-induced hepato and nephrotoxicity via its antioxidant properties. Further investigations should be directed to determination of orally applied FNP poten- 
tial as an organoprotector, as well as the pathways of its activity.

\section{Abbreviations}

AST - Aspartate aminotransferase

DLS - Dinamic light scattering

DMSO - Dimethyl sulfoxide, $\left(\mathrm{CH}_{3}\right)_{2} \mathrm{SO}$

DOX - Doxorubicin, (ALT)-alanine aminotransferase

FNP - Fullerenol, $\mathrm{C}_{60}(\mathrm{OH})_{24}$, nanoparticles

HOPG - Highly orientated pyrolytic graphite

i.p. - Intraperitoneal application

MDA - Malonildialdyhide, AFM-atomic force microscopy

o.a. - Oral application

\section{Acknowledgments}

This work received partial financial supports from the Ministry of Education and Science of the Rebublic of Serbia, Grant no. III 45005, and the Serbian-Slovenian bilateral grant. We are grateful to Dr. Ivan Čapo for the analysis of histological samples and to Dr. Zlatko Rakočević for AFM measurements of FNP.

\section{REFERENCES}

[1] J.L. Quiles, J.R. Huertas, M. Battino, J. mataix, M.C. Ramirez-Tortosa, Antioxidant nutrients and adriamycin toxicity, Toxicology 180 (2002) 79-95.

[2] V. Box, The intercalation of DNA double helices with doxorubicin and nagalomycin, J. Mol. Graph Mod 26 (2007) 14-19.

[3] N. Ashley, J. Poulton, Mitochondrial DNA is a direct target of anti-cancer anthracycline drugs, Biochem. Biophys. Res. Co. 378 (2009) 450-455.

[4] Y. Kalender, M. Yel, S. Kalender, Doxorubicin hepatotoxicity and hepatic free radical metabolism in rats. The effect of vitamin E and catehin, Toxicology 209 (2005) 39-45.

[5] S.V. Kalivendi, E.A. Konorev, S. Cunningham, S.K. Vanamal, E.H. Kaji, J. Joseph, B. Kayanaraman, Doxorubicin activates nuclear factor of activated T-lymphocytes and Fas ligand transcription: role of mitochondrial reactive oxygen species and calcium, Biochem. J. 389 (2005) 527-539.

[6] G. Takemura, H. Fujiwara, Doxorubicin-induced cardiomyopathy from the cardiotoxic mechanisms to management, Prog. Cardiovasc. Dis. 49 (2007) 330-352.

[7] P.K. Singal, N. Iliskovic, Doxorubicin induced cardiomyopathy, N. Engl. J. Med. 339 (1998) 900-905.

[8] R.T.V. Santos, Jr. M.I. Batirsta, E.C. Caperuto, L.F.B.P. Costa Rosa, Chronic supplementation of creatine and vitamins $C$ and $E$ increases survival and improves biochemical parameters after doxorubicin treatment in rats, Clin. Exp. Pharmacol. Physiol. 34 (2007) 1294$-1299$.

[9] E. Winer, M. Morrow, C.K. Osborne, J.R. Harris, in: Cancer: Principles and practice ofoncology, V.T. DeVita, S. Hellman, S.A. Rosenberg (Eds.), Lippincott Williams \& Wilkins, Philadelphia, 2001, pp. 1651-1717.
[10] K. Riehemann, S.W. Schneider, T.A. Luger, B. Godin, M. Ferrari, H. Fuchs, Nanomedicine - challenge and perspectives, Angew. Chem. Int. Ed. Engl. 48 (2009) 872-897.

[11] S.D. Caruthers, S.A. Wickline, G.M. Lanza, Nanotechnological applications in medicine, Curr. Opin. Biotech. 18 (2007) 26-30.

[12] K.K. Jain, Role of nanobiotechnology in the development of personalized medicine, Nanomed. 4 (2009) 249-252.

[13] J.A. Brant, J. Labille, J.Y. Bottero, C.O. Robichaud, M. Wiesner, Fullerol cluster formation in aqueous solutions: Implications for environmental release, J. Colloid Interface Sci. 314 (2007):281-288.

[14] A. Djordjevic, G. Bogdanovic, Archive of Oncology 16 (2008) 42-45.

[15] V. Bogdanovic., K. Stankov, I. Icevic, D. Zikic, A. Nikolic, S. Solajic, A. Djordjevic, G. Bogdanovic, Fullerenol $\mathrm{C}_{60}(\mathrm{OH})_{24}$ effects on antioxidative enzymes activity in irradiated human erythroleukemia cell line, J. Radiat. Res. 49 (2008) 321-327.

[16] S. Trajkovic, S. Dobric, V. Jaćevic, V. Dragojevic-Simic, Z. Milovanovic, A. Djordjevic, Tissue-protective effects of fullerenol $\mathrm{C}_{60}(\mathrm{OH})_{24}$ and amifostine in irradiated rats, Coll. Surf. B. 58 (2007) 39-43.

[17] J. Mrdjanovic, S. Solajic, V.Bogdanovic, Effects of fullerenol $\mathrm{C}_{60}(\mathrm{OH})_{24}$ on the frequency of micronuclei and chromosome aberrations in CHO-K1 cells, Mutat. Res.Gen. Tox. En. 680 (2009) 25-30.

[18] R. Injac, M. Perse, M. Cerne, N. Potocnik, N. Radic, Protective effects of fullerenol $\mathrm{C}_{60}(\mathrm{OH})_{24}$ against doxorubicin-induced cardiotoxicity and hepatotoxicity in rats with colorectal cancer, Biomaterials 30 (2009) 1184$-1196$.

[19] J.J. Yin, F. Lao, P.P.Fu, W.G. Wamer, Y. Zhao, P.C. Wang, Y.Qin, B. Sun, G. Xing, J. Dong, X.J. Liang, C. Chen, The scavenging of reactive oxygen species and the potential for cell protection by functionalized fullerene materials, Biomaterials 30 (2009) 611-621.

[20] X. Jing-Ying, S. Yuan-Yuan, C. Jin-Sheng, L. Shu-Xia, L. Ruili, L. Wen-Xin, X. Guo-Tong, L. Qing-Nuan, Protective effects of fullerenol on carbon tetrachloride-induced acute hepatotoxicity and nephrotoxicity in rats, Carbon 48 (2009) 1388-1396.

[21] A. Djordjevic, M. Vojnovic-Miloradov, N. Petranovic, A. Devecerski, D. Lazar, B. Ribar, Catalytic preparation and characterization of $\mathrm{C}_{60} \mathrm{Br}_{24}$, Fullerene. Sci. Technol. 6 (1998) 689-694.

[22] R. Injac, M. Perse, N. Obermajer, V. Djordjevic-Milic, M. Prijatelj, A. Djordjevic, A. Cerar, B. Strukelj, Potential hepatoprotective effects of fullerenol $\mathrm{C}_{60}(\mathrm{OH})_{24}$ in doxorubicin induced hepatotoxicity in rats with mammary carcinomas, Biomaterials 24-25 (2008) 3451-3460.

[23] R. Injac, M. Boskovic, M. Perse, E. Koprivec-Furlan, A. Djordjevic, Acute doxorubicin nephrotoxicity in rats with malignant neoplasm can be successfully treated with fullerenol $\mathrm{C}_{60}(\mathrm{OH})_{24}$ via suppression of oxidative stress, Pharmacol. Rep. 60 (2008) 742-749.

[24] V. Jacevic, V. Djordjevic-Milic, V. Dragojevic-Simic, N. Radic, B. Govedarica, S. Dobric, B. Srdjenovic, R. Injac, A. Djordjevic, Protective effects of fullerenol $\mathrm{C}_{60}(\mathrm{OH})_{24}$ on 
doxorubicin-induced hepatotoxicity in rats: pathohistological study. Toxicol. Lett. 172 (2007) 146.

[25] R. Injac, M. Perse, M. Boskovic, V. Djordjevic-Milic, A. Djordjevic, A. Hvala, A. Cerar, B. Strukelj, Cardioprotective effects of fullerenol $\mathrm{C}_{60}(\mathrm{OH})_{24}$ on a single dose doxorubicin induced cardiotoxicity in rats with malignant neoplasm, Technol. Cancer. Res. Treat. 7 (2008) $15-26$.
V. Djordjevic-Milic, K. Stankov, R. Injac, A. Djordjevic, B. Srdjenovic, B. Govedarica, N. Radic, V. Dragojevic-Simic, B. Strukelj, Activity of antioxidative enzymes in erythrocytes after a single dose administration of doxorubicin in rats pretreated with fullerenol $\mathrm{C}_{60}(\mathrm{OH})_{24}$. Toxicol. Mech. Method. 19 (2009) 24-28.

\section{IZVOD}

\section{ZAŠTITNI EFEKAT ORALNO UNETIH FULERENOLSKIH NANOČESTICA NA PACOVE NAKON JEDNOKRATRATNE PRIMENE DOKSORUBICINA}

Ivana Đ. Ičević ${ }^{1}$, Saša N. Vukmirović ${ }^{2}$, Branislava U. Srđenović ${ }^{3}$, Jan J. Sudji ${ }^{4}$, Aleksandar N. Djordjevic ${ }^{1}$, Rade M. Injac ${ }^{5}$, Velibor M. Vasović ${ }^{2}$

${ }^{1}$ Departman za hemiju, Prirodno-matematički fakultet, Univerzitet u Novom Sadu, Srbija

${ }^{2}$ Departman za farmakologiju i toksikologiju, Medicinski fakultet, Univerzitet u Novom Sadu, Srbija

${ }^{3}$ Departman za farmaciju, Medicinski fakultet, Univerzitet u Novom Sadu, Srbija

${ }^{4}$ Institut za zdravstvenu zaštitu radnika, Novi Sad, Srbija

${ }^{5}$ Institutu za farmaceutsku biologiju, Fakultet za farmaciju, Univerzitet u Ljubljani, Slovenija

(Naučni rad)

Polihidroksilovane, vodorastvorne nanočestice fulerenola $\mathrm{C}_{60}(\mathrm{OH})_{24}(\mathrm{FNP}) \mathrm{u}$ in vitro i in vivo modelima pokazale su da poseduju višestruke biološke aktivnosti. Doksorubicin (DOX) jeste antraciklinski antibiotik, i jedan od najefikasnijih antineoplastičnih agenasa sa veoma širokim spektrom delovanja. DOX ispoljava niz akutnih i hroničnih neželjenih dejstava, naročito na srce, ali i na druge organe: mozak, bubrege, jetru, skeletnu muskulaturu. Cilj ovog eksperimenta bio je da se ispita potencijalni protektivni efekat oralno aplikovanog fulerenola kod pacova nakon jednokratne intraperitonealne (i.p.) primene doksorubicina (DOX) u dozi od 8 $\mathrm{mg} / \mathrm{kg}$ i to 6 sati nakon poslednje aplikacije fulerenola. Pacovi koji su primili jednokratnu (i.p.) dozu DOX-a imali su statistički značajno veće vrednosti sermske alanin-aminotransferaze (ALT), kao i veće vrednosti nivoa uree u krvi, u poređenju sa ostalim grupama. Životinje iz štićene (FNP/DOX) grupe (grupa V koja je pre aplikacije DOX-a bila tretirana oralno primenjenim fulerenolom) kao i operativne kontrolne grupe (grupa II, tretirana samo fulerenolom) imale su vrednosti nivoa ALT-e i uree u korelaciji sa kontrolnom grupom (grupa I kojoj je oralno aplikovan samo fiziološki rastvor). U svim ispitivanim grupama životinja nije bilo statistički značajnih razlika u nivou serumske aspartat aminotransferaze (AST). Rezultati su pokazali statistički značajno povećanje nivoa malonildialdehida (MDA) u jetri pacova grupe kojoj je jednokratno aplikovan samo DOX. Nivo MDA u štićenoj grupi (FNP/DOX) i operativnoj kontrolnoj grupi bio je u saglasnosti sa rezultatima dobijenim za kontrolnu grupu (grupa I). Statistički značajan porast vrednosti MDA u bubrezima bio je zapažen u grupi kojoj je jednokratno intraperitonealno aplikovan DOX, kao i u grupi koja je primila oralno FNP kao protektor pre tretmana DOX-om (FNP/DOX). Ovo povećanje nivoa MDA u bubrezima bilo je veće u grupi tretiranoj DOX-om u odnosu na štićenu grupu. Vrednosti MDA u kontrolnoj operativnoj grupi u korelaciji su sa onima dobijenim za kontrolnu grupu koja je primila oralno samo fiziološki rastvor. Oralna aplikacija FNP u toku perioda od tri dana u dozama od $10,14,4$ i $21,2 \mathrm{mg} / \mathrm{kg}$ nije izazvala nikakve vidljive patohistološke promene na tkivima bubrega, jetre i tankog creva. Biohemijske i patohistološke analize su pokazale da FNP primenjen oralno u svim navedenim dozama ispoljava protektivnu aktivnost na hepatoksičnost i nefrotoksičnost koje su izazvane jednokratnom (i.p.) primenom DOX-a u dozi od $8 \mathrm{mg} / \mathrm{kg}$.
Ključne reči: Fulerenol • Nanočesice • Doksorubicin $\bullet$ In vivo $\bullet$ Oralna primena 